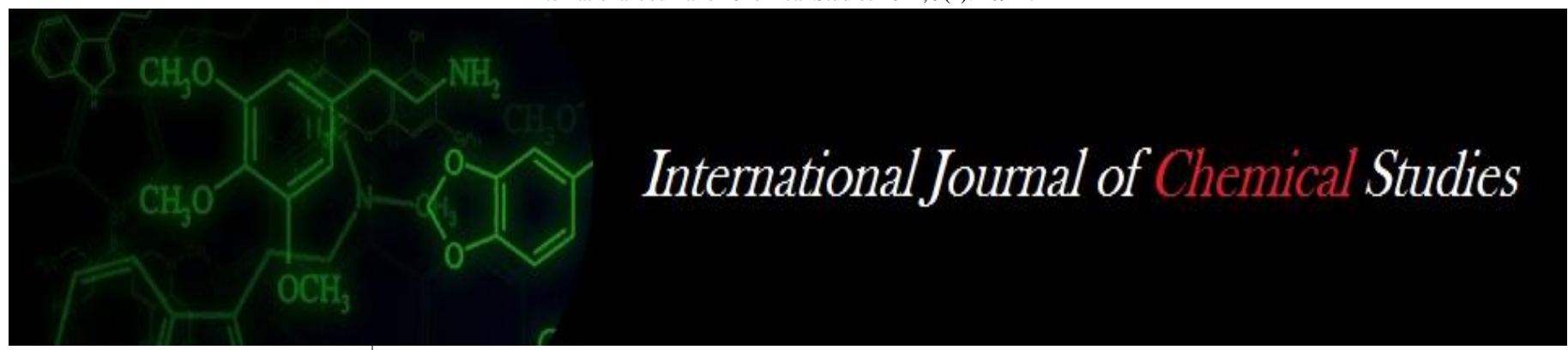

P-ISSN: 2349-8528

E-ISSN: 2321-4902

www.chemijournal.com

IJCS 2021; 9(1): 269-274

(C) 2021 IJCS

Received: 08-10-2020

Accepted: 14-11-2020

\section{Rajesh Kunta}

Department of Crop Physiology,

Professor Jayashankar

Telangana State Agricultural

University, Hyderabad,

Telangana, India

\section{Ramesh Thatikunta}

Department of Crop Physiology,

Professor Jayashankar

Telangana State Agricultural

University, Hyderabad,

Telangana, India

\section{Saida Naik}

Department of Crop Physiology, Professor Jayashankar

Telangana State Agricultural

University, Hyderabad,

Telangana, India

\section{Corresponding Author:}

\section{Rajesh Kunta}

Department of Crop Physiology,

Professor Jayashankar

Telangana State Agricultural

University, Hyderabad,

Telangana, India

\section{Physiological parameters and nitrogen use contribution to yield in rice (Oryza sativa $\mathbf{L}$.)}

\author{
Rajesh Kunta, Ramesh Thatikunta and D Saida Naik
}

DOI: https://doi.org/10.22271/chemi.2021.v9.i1d.11238

\begin{abstract}
A field experiment was conducted to study the genetic variation for nitrogen use efficiency and yield related traits in nine crosses of rice genotypes. Based on the nitrogen use efficiency and yield performance, six rice genotypes viz., MTU-1001, WGL-2395, MTU-1010, Pothana, Bhadrakali and JGL1798 were selected and nine crosses were made. From each cross six generations i.e., $\mathrm{P}_{1}, \mathrm{P}_{2}, \mathrm{~F}_{1}, \mathrm{~F}_{2}, \mathrm{~B}_{1}$ and $\mathrm{B}_{2}$ were generated and analyzed in an experimental trial conducted in rabi, 2012-13. Hybrids showed superior performance. Among the crosses, MTU-1001 X JGL-1798 followed by MTU-1010 X JGL-1798 recorded maximum SCMR values, photosynthetic rate, nitrogen use efficiency and grain yield. The cultivars with high uptake efficiency had higher nitrogen contents than cultivars with low uptake efficiency from nitrogen application. Therefore, selection of hybrids with high uptake efficiency could reduce the losses of nitrogen and facilitates increased nitrogen uptake and yield.
\end{abstract}

Keywords: SCMR values, photosynthetic rate, nitrogen use efficiency and rice yield

\section{Introduction}

Rice (Oryza sativa L.) is one of the major food crops of the world. It is staple food for more than $60 \%$ of the global population and forms the cheapest source of food and energy (Zhao et al., 2011) ${ }^{[22]}$. Besides being the chief source of carbohydrate and protein in Asia, it also provides minerals and fiber. The present world population of 6.3 billion is likely to reach 8.5 billion by 2030 , increasing the demand of rice up to $38 \%$. To meet this challenge there is a need to develop rice varieties with higher yield potential and greater yield stability (Lea and Miflin 2003) ${ }^{[11]}$.

Nitrogen plays an important role in rice production. Increased nitrogen application increases rice yield per unit area and nitrogen fertilizer has a key role in rice life cycle. In the past 50 years, the application of nitrogen fertilizer to rice field resulted in a dramatic increase in yields but with considerable negative impacts on the environment. Continuous increase in rice production has to be achieved with less nitrogen fertilizer by improving nitrogen use efficiency (NUE) through better nitrogen fertilizer management and development of new nitrogen use efficient rice varieties (Ahrens et al. 2010 and Kang et al. 2013) ${ }^{[1,9]}$.

The genotypic variation in NUE has been realized and however, plant traits that are associated with high grain yield and high NUE should be identified so that breeders are able to use these traits easily as selection criteria in the breeding programme to develop nitrogen use efficient varieties without reduction in yield potential. Fundamental approach to develop cultivars with enhanced nitrogen use efficiency, in contrast to just improved yield requires evaluating the segregating population obtained by crossing low nitrogen efficient genotype to high nitrogen use efficient genotype and vice versa under native soil nitrogen condition so as to identify a nitrogen use efficient plants and compare its performance with that of other genotypes. In view of above facts an attempt was made to study genetic response for nitrogen use efficient genotypes with better traits and grain yield in rice generations.

With regard to rice breeding it is very important to know about genetic structure of each trait including inheritability, gene mode of action and number of controller genes. This information makes breeders to design appropriate strategies. Generation mean analysis can be commonly used for evaluating of effect of those genes which are involved in quantitative traits (Kearsy and Pooni, 1996) ${ }^{[10]}$. Estimates of genetic effects using generation mean analysis, genes with additive effects must be completely associated with the parents. 
Therefore, selection of contrasting parents for the trait being measured is crucial for this type of investigation (Wilson et al., 2000) ${ }^{[20]}$.

\section{Materials and Methods}

Based on the yield performance and nitrogen use, six rice genotypes viz., MTU-1001, WGL-2395, MTU-1010, Pothana, Bhadrakali and JGL-1798 were selected from Kharif-2011 and nine crosses viz., MTU- 1001 X Pothana, MTU- $1001 \mathrm{X}$ Bhadrakali, MTU- 1001 X JGL-1798, WGL-2395 X Pothana, WGL-2395 X Bhdrakali, WGL-2395 X JGL-1798, MTU1010 X Pothana, MTU-1010 X Bhadrakali and MTU-1010 X JGL-1798 were made to produce $\mathrm{F}_{1}$ generation in Rabi 201112. $F_{1}$ were selfed to produce $F_{2}$ generations in Kharif 2012 and backcrossed with parents to produce 18 backcross generations. The experiment was carried out in six generations viz., $\mathrm{P}_{1}, \mathrm{P}_{2}, \mathrm{~F}_{1}, \mathrm{~F}_{2}, \mathrm{~B}_{1}$ and $\mathrm{B}_{2}$ and raised during Rabi- 2012-13 at college farm, College of Agriculture, Professor Jayashankar Telangana State Agricultural University, Rajendranagar, Hyderabad. The female and male parents are indicated as $\mathrm{P}_{1}$ and $\mathrm{P}_{2}$. Thirty day old seedlings were transplanted into $6 \mathrm{~m}^{2}(2 \mathrm{~m} \times 3 \mathrm{~m})$ plots by adopting a spacing of $20 \mathrm{~cm}$ between rows and $15 \mathrm{~cm}$ between plants with in a row. The recommended agronomic practices were followed to raise the crop. Five plants in each plot were tagged and observations were recorded on physiological characters at maximum tillering, flowering and maturity stages. The third leaf from top was used for measuring SCMR (SPAD Chlorophyll meter reading), which was taken midway between the leaf base and tip. Mean of five values from five hills at maximum tillering, flowering and maturity stages were recorded. Photosynthetic rate measurements were recorded from leaves that had fully expanded recently by using Infra Red Gas Analyser (IRGA) portable photosynthetic measurement system. During measurements, the Photosynthetically Active Radiation (PAR) was kept at 1200 $\mu \mathrm{mol} \mathrm{m} \mathrm{m}^{-2} \mathrm{~s}^{-1}$ and $\mathrm{CO}_{2}$ concentration at $387 \pm 6 \mathrm{ppm}$. These measurements were made between 10.00 am to 12.00 noon at all the sampling dates and expressed as $\mu \mathrm{mol} \mathrm{CO}_{2} \mathrm{~m}^{-2} \mathrm{~s}^{-1}$.
NUE defined as the ratio of grain yield to applied fertilizer nitrogen is a key parameter for evaluating a crop cultivar. Grain from net plot area was thoroughly sun dried, threshed, cleaned and weight of grains was recorded and expressed in yield per hectare. The data were analyzed statistically following by Singh and Chaudhary (2001) ${ }^{[17]}$.

\section{Results and Discussion}

The performances of six generations $\left(\mathrm{P}_{1}, \mathrm{P}_{2}, \mathrm{~F}_{1}, \mathrm{~F}_{2}, \mathrm{~B}_{1}\right.$ and $\left.\mathrm{B}_{2}\right)$ of nine crosses on grain yield and yield traits have been analyzed and presented. Among the nine crosses, only two crosses viz., MTU-1001 X JGL-1798 and MTU-1010 X JGL1798 recorded improvement in SCMR, photosynthetic rate at flowering stages, nitrogen use efficiency and influenced grain yield.

\section{SPAD Chlorophyll meter reading (SCMR)}

The improvement and contribution of SCMR in rice parents and their subsequent generations is presented (Table 1). SCMR values increased from maximum tillering stage (38.4) to flowering stage (42.2) and thereafter declined towards maturity (33.7). Among the treatments, due to increase in application of nitrogen there was significant increase in SCMR. At maximum tillering stage the mean SCMR value was 37.4 with $60 \mathrm{~kg} \mathrm{~N}$ ha $^{-1}$ which increased to 39.4 with nitrogen $120 \mathrm{~kg} \mathrm{~N} \mathrm{ha}^{-1}$. Plants which were grown in $60 \mathrm{~kg} \mathrm{~N}$ $\mathrm{ha}^{-1}$ recorded the SCMR values of 41.5 at flowering stage which increased to 42.9 with $120 \mathrm{~kg} \mathrm{~N} \mathrm{ha}^{-1}$. Similarly at maturity stage the SCMR value was 32.5 at $60 \mathrm{~kg} \mathrm{~N}^{-1}$ which increased to 35.0 with $120 \mathrm{~kg} \mathrm{~N}^{-1}$. Non significant differences were observed among the parents in SCMR at maximum tillering and flowering stage, but significant differences were observed at maturity stage and values ranged from 33.1 to 34.7. Maximum SCMR values were recorded in parent MTU-1001 (34.7) where as minimum was recorded in parent JGL-1798 (33.1) at maturity stage. The interaction effects between nitrogen levels and parents for SCMR were non significant at all the crop growth stages.

Table 1: SCMR values in rice parents as influenced by nitrogen supply at different crop growth stages during rabi-2012-13

\begin{tabular}{|c|c|c|c|c|c|c|c|c|c|c|}
\hline \multirow{2}{*}{\multicolumn{2}{|c|}{ Parents }} & \multicolumn{3}{|c|}{ At maximum tillering stage } & \multicolumn{3}{|c|}{ At flowering stage } & \multicolumn{3}{|c|}{ At maturity stage } \\
\hline & & \begin{tabular}{|c|}
$60 \mathrm{~kg} \mathrm{~N} \mathrm{ha}^{-1}$ \\
\end{tabular} & $120 \mathrm{~kg} \mathrm{~N} \mathrm{ha}^{-1}$ & Mean & 60 kg N ha & $120 \mathrm{~kg} \mathrm{~N} \mathrm{ha}^{-1}$ & Mean & $60 \mathrm{~kg} \mathrm{~N} \mathrm{ha}^{-1}$ & $120 \mathrm{~kg} \mathrm{~N} \mathrm{ha}^{-1}$ & Mean \\
\hline \multicolumn{2}{|c|}{ WGL-2395 } & 37.0 & 39.7 & 38.4 & 41.7 & 42.4 & 42.0 & 33.4 & 35.4 & 34.4 \\
\hline \multicolumn{2}{|c|}{ Pothana } & 36.6 & 39.0 & 37.8 & 41.1 & 42.5 & 41.8 & 31.9 & 35.0 & 33.5 \\
\hline \multicolumn{2}{|c|}{ MTU-1001 } & 38.2 & 40.2 & 39.2 & 42.3 & 43.5 & 42.9 & 33.6 & 35.7 & 34.7 \\
\hline \multicolumn{2}{|c|}{ Bhadrakali } & 37.2 & 38.3 & 37.8 & 40.6 & 42.7 & 41.6 & 31.7 & 34.7 & 33.2 \\
\hline \multicolumn{2}{|c|}{ JGL-1798 } & 37.7 & 39.4 & 38.5 & 41.5 & 42.8 & 42.1 & 31.8 & 34.4 & 33.1 \\
\hline \multicolumn{2}{|c|}{ MTU-1010 } & 37.6 & 40.0 & 38.8 & 42.1 & 43.6 & 42.9 & 32.6 & 34.7 & 33.6 \\
\hline \multicolumn{2}{|r|}{ Mean } & 37.4 & 39.4 & 38.4 & 41.5 & 42.9 & 42.2 & 32.5 & 35.0 & 33.7 \\
\hline \multirow{3}{*}{$\mathrm{CD}(5 \%)$} & Treatments (T) & \multicolumn{3}{|c|}{1.543} & \multicolumn{3}{|c|}{1.287} & \multicolumn{3}{|c|}{1.698} \\
\hline & Parents (P) & \multirow{2}{*}{\multicolumn{3}{|c|}{ NS }} & \multirow{2}{*}{\multicolumn{3}{|c|}{ NS }} & \multicolumn{3}{|c|}{1.087} \\
\hline & T X P & & & & & & & \multicolumn{3}{|c|}{ NS } \\
\hline
\end{tabular}

\section{Improvement and contribution of SCMR}

In the cross MTU-1001 X JGL-1798, significant difference was observed between generations (Table 5). Parent $\mathrm{P}_{1}$ recorded higher SCMR at tillering stage (39.67) than parent $P_{2}$ (39.37). The hybrid $F_{1}$ recorded significantly higher value than parents (40.77). $\mathrm{F}_{2}$ recorded lower SCMR at tillering stage (38.17). Back crosses $B_{1}$ (39.64) and $B_{2}$ (39.40) were significant and on par with parents. Parent $\mathrm{P}_{2}$ (42.77) recorded higher SCMR than parent $\mathrm{P}_{1}(42.37)$ at flowering stage. The hybrid $F_{1}$ (45.67) recorded higher SCMR compared to all generations. $\mathrm{F}_{2}$ (40.94) recorded lower SCMR values at flowering stage compared to parents. Among back crosses, $\mathrm{B}_{1}$ (43.03) recorded slightly higher value than $\mathrm{B}_{2}$ (42.89) and superior to both parents. No significant differences were observed among the generations for SCMR at maturity stage. In the cross MTU-1010 X JGL-1798 with respect to SCMR (Table 6) similar to the above cross recorded significantly higher value were recorded than parents in the hybrid $F_{1}$ at tillering (40.53) and flowering stage (45.27). The promotive effect could not be observed at maturity stage.

Islam et al. (2009) ${ }^{[8]}$ reported the relationship between leaf $\mathrm{N}$ content and SPAD value indicating that the rice leaves 
showing higher SCMR readings (>35) had higher chlorophyll and nitrogen contents. Singh et al. (2002) ${ }^{[16]}$ reported plant need based nitrogen management though chlorophyll meter can reduce $\mathrm{N}$ requirement of rice from 12.5 to $25 \%$, with no loss in yield. Miah and Ahmed (2002) ${ }^{[13]}$ also reported that SCMR meter based nitrogen management appeared to be more efficient and would save $20-30 \mathrm{~kg} \mathrm{~N} \mathrm{ha}^{-1}$ than conventional nitrogen management practices to produce similar grain yield.

\section{Photosynthetic rate $\left(\mu \mathrm{mol} \mathrm{CO}_{2} \mathrm{~m}^{-2} \mathrm{~s}^{-1}\right)$}

There was increase in photosynthetic rate from maximum tillering $\left(18.14 \mu \mathrm{mol} \mathrm{CO} \mathrm{CO}^{-2} \mathrm{~s}^{-1}\right)$ to flowering stage $(22.26 \mu$ mol $\mathrm{CO}_{2} \mathrm{~m}^{-2} \mathrm{~s}^{-1}$ ) and which decreased there after towards maturity stage $\left(13.13 \mu \mathrm{mol} \mathrm{CO} \mathrm{C}^{-2} \mathrm{~s}^{-1}\right)$ (Table 2). Increase in photosynthetic rate with increase in nitrogen application from 60 to $120 \mathrm{Kg} \mathrm{N} \mathrm{ha}^{-1}$ was recorded at all the three stages which was statistically significant. At maximum tillering stage the increase was from 16.92 to $19.37 \mu \mathrm{mol} \mathrm{CO}_{2} \mathrm{~m}^{-2} \mathrm{~s}^{-1}$, at flowering stage from 20.94 to $23.57 \mu \mathrm{mol} \mathrm{CO}_{2} \mathrm{~m}^{-2} \mathrm{~s}^{-1}$ while at maturity stage from 12.59 to $13.66 \mu \mathrm{mol} \mathrm{CO} \mathrm{Cm}^{-2} \mathrm{~s}^{-1}$ with increase of nitrogen from 60 to $120 \mathrm{Kg} \mathrm{N}^{-1}$ respectively. Significant differences were observed between the parents in photosynthetic rate at maximum tillering and flowering stage, but the differences were non significant at maturity stage. The maximum values were recorded in MTU-1001 at both maximum tillering and flowering stages (18.86 and $23.11 \mu$ mol $\left.\mathrm{CO}_{2} \mathrm{~m}^{-2} \mathrm{~s}^{-1}\right)$. Bhadrakali recorded minimum at maximum tillering $\left(17.36 \mu \mathrm{mol} \mathrm{CO} \mathrm{C}^{-2} \mathrm{~s}^{-1}\right)$ and flowering stages $(21.48$ $\left.\mu \mathrm{mol} \mathrm{CO} \mathrm{C}^{-2} \mathrm{~s}^{-1}\right)$. The interaction effects between nitrogen levels and parents for photosynthetic rate were non significant at all the crop growth stages.

Table 2: Photosynthetic rate $\left(\mu \mathrm{mol} \mathrm{CO} 2 \mathrm{~m}^{-2} \mathrm{~s}^{-1}\right)$ in rice parents as influenced by nitrogen supply at different crop growth stages during rabi2012-13

\begin{tabular}{|c|c|c|c|c|c|c|c|c|c|c|}
\hline \multirow{2}{*}{\multicolumn{2}{|c|}{ Parents }} & \multicolumn{3}{|c|}{ At maximum tillering stage } & \multicolumn{3}{|c|}{ At flowering stage } & \multicolumn{3}{|c|}{ At maturity stage } \\
\hline & & $60 \mathrm{~kg} \mathrm{~N} \mathrm{ha}^{-1}$ & $120 \mathrm{~kg} \mathrm{~N} \mathrm{ha}^{-1}$ & Mean & $60 \mathrm{~kg} \mathrm{~N} \mathrm{ha}^{-1}$ & $120 \mathrm{~kg} \mathrm{~N} \mathrm{ha}^{-1}$ & Mean & $60 \mathrm{~kg} \mathrm{~N} \mathrm{ha}^{-1}$ & $120 \mathrm{~kg} \mathrm{~N} \mathrm{ha}^{-1}$ & Mean \\
\hline \multicolumn{2}{|c|}{ WGL-2395 } & 17.37 & 19.72 & 18.55 & 20.80 & 23.81 & 22.31 & 12.53 & 13.41 & 12.97 \\
\hline \multicolumn{2}{|c|}{ Pothana } & 16.20 & 18.64 & 17.42 & 20.43 & 22.79 & 21.61 & 12.80 & 14.31 & 13.55 \\
\hline \multicolumn{2}{|c|}{ MTU-1001 } & 17.67 & 20.04 & 18.86 & 21.85 & 24.36 & 23.11 & 12.19 & 13.08 & 12.64 \\
\hline \multicolumn{2}{|c|}{ Bhadrakali } & 16.19 & 18.53 & 17.36 & 20.25 & 22.72 & 21.48 & 12.86 & 14.49 & 13.68 \\
\hline \multicolumn{2}{|c|}{ JGL-1798 } & 16.48 & 19.18 & 17.83 & 20.52 & 23.53 & 22.03 & 12.73 & 13.50 & 13.11 \\
\hline \multicolumn{2}{|c|}{ MTU-1010 } & 17.62 & 20.07 & 18.85 & 21.82 & 24.22 & 23.02 & 12.40 & 13.20 & 12.80 \\
\hline \multicolumn{2}{|r|}{ Mean } & 16.92 & 19.37 & 18.14 & 20.94 & 23.57 & 22.26 & 12.59 & 13.66 & 13.13 \\
\hline \multirow{3}{*}{$\mathrm{CD}(5 \%)$} & Treatments (T) & \multicolumn{3}{|c|}{0.853} & \multicolumn{3}{|c|}{1.252} & \multicolumn{3}{|c|}{0.219} \\
\hline & Parents (P) & \multicolumn{3}{|c|}{0.724} & \multicolumn{3}{|c|}{1.103} & \multicolumn{3}{|c|}{ NS } \\
\hline & T X P & \multicolumn{3}{|c|}{ NS } & \multicolumn{3}{|c|}{ NS } & \multicolumn{3}{|c|}{ NS } \\
\hline
\end{tabular}

\section{Improvement and contribution of Photosynthetic rate}

In the cross MTU-1001 X JGL-1798, Photosynthetic rate (Table 5) at tillering stage for parent $\mathrm{P}_{1}\left(19.72 \mu \mathrm{mol} \mathrm{CO} \mathrm{CO}^{-2}\right.$ $\mathrm{s}^{-1}$ ) recorded on par values with parent $\mathrm{P}_{2}$ (19.18). The hybrid $\mathrm{F}_{1}$ recorded higher photosynthetic rate compared to all generations $\left(21.27 \mu \mathrm{mol} \mathrm{CO}_{2} \mathrm{~m}^{-2} \mathrm{~s}^{-1}\right) . \mathrm{F}_{2}$ recorded better value than parents $\left(20.55 \mu \mathrm{mol} \mathrm{CO} \mathrm{m}^{-2} \mathrm{~s}^{-1}\right)$. Among the back crosses, $\mathrm{B}_{1}\left(20.83 \mu \mathrm{mol} \mathrm{CO} \mathrm{Cm}^{-2} \mathrm{~s}^{-1}\right)$ was almost similar to $\mathrm{B}_{2}$ (20.16 $\left.\mu \mathrm{mol} \mathrm{CO}_{2} \mathrm{~m}^{-2} \mathrm{~s}^{-1}\right)$. Photosynthetic rate at flowering stage for parent $\mathrm{P}_{1}\left(23.81 \mu \mathrm{mol} \mathrm{CO} \mathrm{CO}^{-2} \mathrm{~s}^{-1}\right)$ was on par with parent $\mathrm{P}_{2}\left(23.53 \mu \mathrm{mol} \mathrm{CO} \mathrm{Cm}^{-2} \mathrm{~s}^{-1}\right)$. The hybrid $\mathrm{F}_{1}(27.66 \mu$ mol $\mathrm{CO}_{2} \mathrm{~m}^{-2} \mathrm{~s}^{-1}$ ) recorded higher photosynthetic rate compared to all generations. $\mathrm{F}_{2}\left(26.15 \mu \mathrm{mol} \mathrm{CO}_{2} \mathrm{~m}^{-2} \mathrm{~s}^{-1}\right)$ recorded higher values than both parents. Among the back crosses, $\mathrm{B}_{1}\left(26.39 \mu \mathrm{mol} \mathrm{CO} \mathrm{Cm}^{-2} \mathrm{~s}^{-1}\right)$ was higher than $\mathrm{B}_{2}$ (24.477 $\mu \mathrm{mol} \mathrm{CO}_{2} \mathrm{~m}^{-2} \mathrm{~s}^{-1}$ ) and both of them were significantly superior to parents. Photosynthetic rate at maturity stage for parent $\mathrm{P}_{2}\left(13.50 \mu \mathrm{mol} \mathrm{CO} \mathrm{Cm}^{-2} \mathrm{~s}^{-1}\right)$ was on par with parent $\mathrm{P}_{1}\left(13.41 \mu \mathrm{mol} \mathrm{CO}_{2} \mathrm{~m}^{-2} \mathrm{~s}^{-1}\right)$. The hybrid $\mathrm{F}_{1}$ (16.28 $\left.\mu \mathrm{mol} \mathrm{CO} \mathrm{CO}^{-2} \mathrm{~s}^{-1}\right)$ recorded higher photosynthetic rate

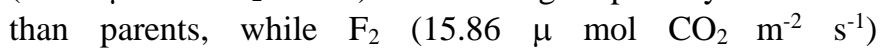
photosynthetic rate was better than parents. Among the back crosses, $\mathrm{B}_{2}\left(15.94 \mu \mathrm{mol} \mathrm{CO} \mathrm{m}^{-2} \mathrm{~s}^{-1}\right)$ was higher than $\mathrm{B}_{1}$ $\left(15.06 \mu \mathrm{mol} \mathrm{CO}_{2} \mathrm{~m}^{-2} \mathrm{~s}^{-1}\right)$.

In the cross MTU-1010 X JGL-1798 with respect to photosynthetic rate (Table 6) similar to the above cross recorded significantly higher value than parents in the hybrid $\mathrm{F}_{1}$ at tillering $\left(20.99 \mu \mathrm{mol} \mathrm{CO} \mathrm{Cm}^{-2} \mathrm{~s}^{-1}\right)$, at flowering $(27.35 \mu$ $\left.\mathrm{mol} \mathrm{CO} 2 \mathrm{~m}^{-2} \mathrm{~s}^{-1}\right)$ and at maturity stage $\left(16.59 \mu \mathrm{mol} \mathrm{CO}_{2} \mathrm{~m}^{-2} \mathrm{~s}\right.$ $1)$.
Hassan et al. (2007) ${ }^{[7]}$ observed significant differences in photosynthetic activity at flowering under variable nutrient levels of rice. High nutrient level recorded significantly high photosynthetic rate followed by medium nutrient level and control. At low nitrogen levels, there was significant reduction in the net photosynthetic rate in rice cultivars (Ligeng et al., 2005) ${ }^{[12]}$. Genotypes maintaining higher leaf chlorophyll content during crop growth period may be considered as potential donors for the ability of producing higher photosynthetic rate in leaf blades (Miah et al., 1997) ${ }^{[14]}$. Win and Mochizuki (2010) ${ }^{[21]}$ observed that a high rate of photosynthesis with low leaf nitrogen content is a desirable physiological trait for improving nitrogen use efficiency of rice.

\section{Number of filled grains hill ${ }^{-1}$ and 1000 grain weight (g)}

The data on number of filled grains hill $^{-1}$ as influenced by nitrogen application in parents is presented (Table 3). There was significant increase in number of filled grains hill ${ }^{-1}$ with increase in nitrogen application. Application of nitrogen at $120 \mathrm{~kg} \mathrm{ha}^{-1}$ has resulted in maximum number of filled grains $\operatorname{hill}^{-1}(1415)$ while at $60 \mathrm{~kg} \mathrm{~N}^{-1}$ it was minimum (1243). The differences among the parents for number of filled grains hill ${ }^{1}$ are statistically significant which ranged from 1183 to 1499 . The parent MTU-1001 recorded maximum number of 1499 filled grains hill $^{-1}$ followed by MTU-1010 (1446 filled grains hill $^{-1}$ ) while minimum number of filled grains hill-1 ${ }^{-1}(183)$ was recorded in Bhadrakali. The interaction between nitrogen levels and parents were also statistically significant which ranged from 1069 to 1565 . MTU-1001 recorded maximum number of filled grains hill-1 ${ }^{-1}(1565)$ while minimum number 
of filled grains hill ${ }^{-1}$ (1297) was recorded in Bhadrakali at 120 $\mathrm{kg} \mathrm{N} \mathrm{ha}^{-1}$. The 1000 grain weight was significantly influenced by nitrogen application in rice parents which ranged from 15.70 to $17.60 \mathrm{~g}$ (Table 3). Significant increase in test weight with increase in nitrogen application was recorded. Maximum weight of $17.60 \mathrm{~g}$ was recorded at $120 \mathrm{~kg} \mathrm{~N} \mathrm{ha}^{-1}$, whereas at $60 \mathrm{~kg} \mathrm{~N} \mathrm{ha}{ }^{-1}$ the value was $15.70 \mathrm{~g}$. Among the parents significant difference for 1000 grain weight ranged from $14.53 \mathrm{~g}$ (Bhadrakali) to $20.05 \mathrm{~g}$ (MTU-1010). The interaction effect between nitrogen levels and parents were significant for 1000 grain weight which ranged from 14.02 to $22.05 \mathrm{~g}$. Among the interaction MTU-1010 has recorded maximum 1000 grain weight of $22.05 \mathrm{~g}$, whereas Bhadrakali recorded minimum grain weight of $15.05 \mathrm{~g}$ at $120 \mathrm{~kg} \mathrm{~N} \mathrm{ha}^{-1}$.

Table 3: Number of filled grains hill ${ }^{-1}$ and 1000 grain weight (g) of rice parents as influenced by nitrogen supply in rabi 2012-13

\begin{tabular}{|c|c|c|c|c|c|c|c|}
\hline \multirow{2}{*}{\multicolumn{2}{|c|}{ Parents }} & \multicolumn{3}{|c|}{ Number of filled grains hill ${ }^{-1}$} & \multicolumn{3}{|c|}{1000 grain weight $(\mathrm{g})$} \\
\hline & & $60 \mathrm{~kg} \mathrm{~N} \mathrm{ha}^{-1}$ & $120 \mathrm{~kg} \mathrm{~N} \mathrm{ha}^{-1}$ & Mean & $60 \mathrm{~kg} \mathrm{~N} \mathrm{ha}^{-1}$ & $120 \mathrm{~kg} \mathrm{~N} \mathrm{ha}^{-1}$ & Mean \\
\hline & $\mathrm{L}-2395$ & 1294 & 1294 & 1294 & 15.04 & 16.58 & 15.81 \\
\hline \multicolumn{2}{|c|}{ Pothana } & 1102 & 1102 & 1102 & 14.25 & 15.39 & 14.82 \\
\hline \multicolumn{2}{|c|}{ MTU-1001 } & 1432 & 1432 & 1432 & 17.47 & 20.09 & 18.78 \\
\hline \multicolumn{2}{|c|}{ Bhadrakali } & 1069 & 1069 & 1069 & 14.02 & 15.05 & 14.53 \\
\hline \multicolumn{2}{|c|}{ JGL-1798 } & 1171 & 1171 & 1171 & 15.37 & 16.46 & 15.91 \\
\hline \multicolumn{2}{|c|}{ MTU-1010 } & 1388 & 1388 & 1388 & 18.04 & 22.05 & 20.05 \\
\hline \multicolumn{2}{|c|}{ Mean } & 1243 & 1243 & 1243 & 15.70 & 17.60 & 16.65 \\
\hline \multirow{3}{*}{$\mathrm{CD}(5 \%)$} & Treatments $(\mathrm{T})$ & \multicolumn{3}{|c|}{40.202} & \multicolumn{3}{|c|}{0.149} \\
\hline & Parents $(\mathrm{P})$ & \multicolumn{3}{|c|}{20.518} & \multicolumn{3}{|c|}{0.194} \\
\hline & T X P & \multicolumn{3}{|c|}{45.053} & \multicolumn{3}{|c|}{0.282} \\
\hline
\end{tabular}

\section{Improvement and contribution of filled grains hill $^{-1}$ and yield}

In the cross MTU-1001 X JGL-1798, number of filled grains hill ${ }^{-1}$ for parent $\mathrm{P}_{1}$ (1458.67) significantly recorded higher than the parent $\mathrm{P}_{2}(1352.67)$ (Table 5). The hybrid $\mathrm{F}_{1}$ (1603.33) recorded higher value than all generations. $F_{2}$ (1525.60) generation values were also higher than both the parents. Among the back crosses, $B_{1}$ (1527.51) showed higher value than to $B_{2}$ (1386.17) for number of filled grains hill ${ }^{-1}$. 1000 grain weight was significantly different in both the parents and parent $\mathrm{P}_{1}(16.58 \mathrm{~g})$ which recorded values on par with 1000 grain weight than $\mathrm{P}_{2}(16.46 \mathrm{~g})$. The hybrid $\mathrm{F}_{1}$ (18.56 g) recorded maximum 1000 grain weight than the $F_{2}$ (17.51 g). Among the back crosses, significant differences were observed between $\mathrm{B}_{1}(17.25 \mathrm{~g})$ and $\mathrm{B}_{2}(15.70 \mathrm{~g})$ and $\mathrm{B}_{1}$ was higher in 1000 grain weight than parents. Parent $\mathrm{P}_{1}$ $\left(5155.27 \mathrm{~kg} \mathrm{ha}^{-1}\right)$ recorded higher grain yield than parent $\mathrm{P}_{2}$ $\left(5120.63 \mathrm{~kg} \mathrm{ha}^{-1}\right)$. Among the entire generations, the hybrid $\mathrm{F}_{1}$ $\left(5581.30 \mathrm{~kg} \mathrm{ha}^{-1}\right)$ recorded maximum grain yield, while $\mathrm{F}_{2}$ $\left(5162.52 \mathrm{~kg} \mathrm{ha}^{-1}\right)$ yielded higher grain yield than the parents. Among the back crosses, $\mathrm{B}_{1}\left(5374.48 \mathrm{~kg} \mathrm{ha}^{-1}\right)$ recorded more yield than $\mathrm{B}_{2}\left(5182.30 \mathrm{~kg} \mathrm{ha}^{-1}\right)$, which in turn yielded more than both parents.

In the cross MTU-1010 X JGL-1798, significant difference was observed between generations (Table 6). $F_{1}$ (1578.67) hybrid recorded higher number of filled grains hill-1 among all the generations. The hybrid $F_{1}(19.93 \mathrm{~g})$ recorded maximum 1000 grain weight than the $F_{2}(18.38 \mathrm{~g})$. Among the back crosses, no significant differences were observed between $\mathrm{B}_{1}$ $(15.65 \mathrm{~g})$ and $\mathrm{B}_{2}(15.37 \mathrm{~g})$. Among the entire generations, the hybrid $F_{1}\left(5539.80 \mathrm{~kg} \mathrm{ha}^{-1}\right)$ recorded maximum grain yield, while $\mathrm{F}_{2}\left(5153.04 \mathrm{~kg} \mathrm{ha}^{-1}\right)$ yielded higher grain yield than parent $\mathrm{P}_{2}$

Bharali and Chandra (1994) [3] reported that factors like adaptability, temperature, soil fertility, transplantation season and time were responsible for 1000 grain weight. Tahir et al. (2002) ${ }^{[19]}$ reported highly significant variation of thousand grain weight in different traits of rice and observed that these traits are under the control of genotypic difference among the genotypes. Nitrogen contributes to carbohydrate accumulation in culms and leaf sheaths during the pre-heading stage and in the grain during the ripening stage of rice (Swain et al, 2010) [18]. Accumulation of nitrogen elements in rice reproductive organs and its distribution are important process which determines the grain yield (Bahmanyar and Ranjbar, 2007) ${ }^{[2]}$.

\section{Nitrogen Use Efficiency (NUE) and Grain yield (kg ha-1)}

Significant differences were observed between the treatments and increase in nitrogen application reduced the NUE to 43.05 (120 kg N ha-1) from 82.22 (60 $\mathrm{kg} \mathrm{N} \mathrm{ha}^{-1}$ ) (Table 4). The results showed that the NUE did not increase linearly with the amount of nitrogen application. Kang et al. (2013) ${ }^{[9]}$ reported that higher nitrogen levels showed significantly lower NUE values. Among the parents, MTU-1001 recorded maximum NUE of 64.23 and Bhadrakali recorded the minimum NUE of 61.04. The interaction between nitrogen levels and parents were significant. NUE ranged from 41.63 to 83.65. MTU1001 recorded maximum NUE of 83.65 and Bhadrakali recorded minimum NUE of 80.45 at $60 \mathrm{~kg} \mathrm{~N}^{-1}$.

The adequate quantity of nitrogen $\left(120 \mathrm{~kg} \mathrm{~N} \mathrm{ha}^{-1}\right)$ helped rice plants to promote the yield attributing characters. The data on grain yield indicated significant improvement in grain yield with increase in nitrogen application in rice parents which ranged from 4933 at $60 \mathrm{~kg} \mathrm{~N} \mathrm{ha}^{-1}$ to $5166 \mathrm{~kg} \mathrm{ha}^{-1}$ at $120 \mathrm{~kg} \mathrm{~N}$ $\mathrm{ha}^{-1}$ (Table 4). The grain yield among parents MTU-1001 recorded maximum grain yield of $5199 \mathrm{~kg} \mathrm{ha}^{-1}$, while the minimum grain yield of $4912 \mathrm{~kg} \mathrm{ha}^{-1}$ was recorded by Bhadrakali. The interaction effect between nitrogen levels and rice parents were significant for grain yield with 4827 to 5378 $\mathrm{kg} \mathrm{ha}{ }^{-1}$. Among the interaction combinations, MTU-1001 recorded maximum grain yield of $5378 \mathrm{~kg} \mathrm{ha}^{-1}$, whereas minimum grain yield of $4996 \mathrm{~kg} \mathrm{ha}^{-1}$ recorded in Bhadrakali at $120 \mathrm{~kg} \mathrm{~N} \mathrm{ha}^{-1}$.

Table 4: Grain yield $\left(\mathrm{kg} \mathrm{ha}^{-1}\right)$ and Nitrogen Use Efficiency (NUE) and of rice parents as influenced by nitrogen supply in rabi 2012-13

\begin{tabular}{|c|c|c|c|c|c|c|}
\hline \multirow[b]{2}{*}{ Parents } & \multicolumn{3}{|c|}{ Grain yield $\left(\mathrm{kg} \mathrm{ha}^{-1}\right)$} & \multicolumn{3}{|c|}{ Nitrogen Use Efficiency (NUE) } \\
\hline & $60 \mathrm{~kg} \mathrm{~N} \mathrm{ha}^{-1}$ & $120 \mathrm{~kg} \mathrm{~N} \mathrm{ha}^{-1}$ & Mean & $60 \mathrm{~kg} \mathrm{~N} \mathrm{ha}^{-1}$ & $120 \mathrm{~kg} \mathrm{~N} \mathrm{ha}^{-1}$ & Mean \\
\hline WGL-2395 & 4983 & 5155 & 5069 & 83.05 & 42.96 & 63.00 \\
\hline Pothana & 4859 & 5033 & 4946 & 80.98 & 41.94 & 61.46 \\
\hline
\end{tabular}




\begin{tabular}{|c|c|c|c|c|c|c|c|}
\hline \multicolumn{2}{|c|}{ MTU-1001 } & 5019 & 5378 & 5199 & 83.65 & 44.82 & 64.23 \\
\hline \multicolumn{2}{|c|}{ Bhadrakali } & 4827 & 4996 & 4912 & 80.45 & 41.63 & 61.04 \\
\hline \multicolumn{2}{|c|}{ JGL-1798 } & 4908 & 5121 & 5014 & 81.80 & 42.67 & 62.24 \\
\hline \multicolumn{2}{|c|}{ MTU-1010 } & 5004 & 5312 & 5158 & 83.39 & 44.26 & 63.83 \\
\hline \multicolumn{2}{|c|}{ Mean } & 4933 & 5166 & 5050 & 82.22 & 43.05 & 62.63 \\
\hline \multirow{3}{*}{ C.D $(5 \%)$} & Treatments $(\mathrm{T})$ & \multicolumn{3}{|c|}{26.653} & \multicolumn{3}{|c|}{0.392} \\
\hline & Parents $(\mathrm{P})$ & \multicolumn{3}{|c|}{36.887} & \multicolumn{3}{|c|}{0.406} \\
\hline & T X P & \multicolumn{3}{|c|}{52.894} & \multicolumn{3}{|c|}{0.626} \\
\hline
\end{tabular}

\section{Improvement and contribution of Nitrogen use efficiency}

In the cross MTU-1001 X JGL-1798 NUE of parent $\mathrm{P}_{1}$ (42.96) recorded was higher than parent $\mathrm{P}_{2}$ (42.67) (Table 5). The hybrid $F_{1}$ (46.51) recorded higher NUE compared to all generations. $F_{2}$ (43.02) recorded higher NUE than parent. Among the back crosses, significant differences were observed between $B_{1}$ (44.79) and $B_{2}$ (43.19) and $B_{1}$ was higher in NUE than and parents. In the cross MTU-1010 X JGL-1798 (Table 6) the hybrid $F_{1}$ recorded higher NUE compared to all generations (46.17). $\mathrm{F}_{2}$ recorded lower NUE (42.94) than better parent. Among the back crosses, significant differences were observed and $\mathrm{B}_{1}$ (43.77) recorded higher NUE than $B_{2}$ (42.71). Rice varieties respond well to higher levels of nitrogen but nitrogen use efficiency is comparatively better at lower nitrogen levels (Cassman et al., 1993) ${ }^{[4]}$. The current average NUE in the field is approximately $33 \%$ and a substantial proportion of the remaining $67 \%$ is lost into the environment, especially in the intensively cropped areas (Pathak et al., 2008) ${ }^{[15]}$. Unlike other quantitative traits, NUE is one which had produced favourable results showing the effectiveness of this approach in selecting genotypes positively contributing to high nitrogen use efficiency.

MTU-1001X JGL-1798 shows superiority of six characters and was on par with parents for SCMR at maturity stage. $F_{1}$ better performance observed and yield was also reflected in 1000 grain weight and has a basis in NUE.

Table 5: Mean performance of MTU-1001 X JGL-1798 with respect to SCMR, photosynthetic rate and yield related traits of rice during rabi, 2012-13

\begin{tabular}{|c|c|c|c|c|c|c|c|c|}
\hline \multirow{2}{*}{ Trait/Cross } & \multicolumn{8}{|c|}{ MTU-1001 X JGL-1798 } \\
\hline & $\mathbf{P}_{1}$ & $\mathbf{P}_{2}$ & $\mathbf{F}_{1}$ & $\mathbf{F}_{2}$ & $\mathbf{B}_{1}$ & $\mathbf{B}_{2}$ & S.Em \pm & C.D (5\%) \\
\hline SCMR at tillering stage & 39.67 & 39.37 & 40.77 & 38.17 & 39.64 & 39.40 & 0.47 & 1.35 \\
\hline SCMR at flowering stage & 42.37 & 42.77 & 45.67 & 40.94 & 43.03 & 42.89 & 0.58 & 1.68 \\
\hline SCMR at maturity stage & 35.37 & 34.43 & 34.70 & 33.17 & 32.88 & 33.17 & 0.44 & 1.27 \\
\hline Photosynthetic rate at tillering stage $\left(\mu \mathrm{mol} \mathrm{CO}_{2} \mathrm{~m}^{-2} \mathrm{~s}^{-1}\right)$ & 19.72 & 19.18 & 21.27 & 20.55 & 20.83 & 20.16 & 0.49 & 1.42 \\
\hline Photosynthetic rate at flowering stage $\left(\mu \mathrm{mol} \mathrm{CO}_{2} \mathrm{~m}^{-2} \mathrm{~s}^{-1}\right)$ & 23.81 & 23.53 & 27.66 & 26.15 & 26.39 & 24.77 & 0.68 & 1.96 \\
\hline Photosynthetic rate at maturity stage $\left(\mu \mathrm{mol} \mathrm{CO} \mathrm{m}^{-2} \mathrm{~s}^{-1}\right)$ & 13.41 & 13.50 & 16.28 & 15.86 & 15.06 & 15.94 & 0.41 & 1.20 \\
\hline No. of filled grains hill-1 & 1458.67 & 1352.67 & 1603.33 & 1525.60 & 1527.51 & 1386.17 & 30.93 & 89.31 \\
\hline 1000 grain wt $(\mathrm{g})$ & 16.58 & 16.46 & 18.56 & 17.51 & 17.25 & 15.70 & 0.27 & 0.79 \\
\hline NUE & 42.96 & 42.67 & 46.51 & 43.02 & 44.79 & 43.19 & 0.38 & 1.10 \\
\hline Grain yield $\left(\mathrm{kg} \mathrm{ha}^{-1}\right)$ & 5155.27 & 5120.63 & 5581.30 & 5162.52 & 5374.48 & 5182.30 & 40.17 & 115.99 \\
\hline
\end{tabular}

Table 6: Mean performance of MTU-1010 X JGL-1798 with respect to SCMR, photosynthetic rate and yield related traits of rice during rabi, $2012-13$

\begin{tabular}{|c|c|c|c|c|c|c|c|c|}
\hline \multirow{2}{*}{ Trait/cross } & \multicolumn{8}{|c|}{ MTU-1010 X JGL-1798 } \\
\hline & $\mathbf{P}_{1}$ & $\mathbf{P}_{2}$ & $\mathbf{F}_{1}$ & $\mathbf{F}_{2}$ & $\mathbf{B}_{1}$ & $\mathbf{B}_{2}$ & S.Em \pm & C.D (5\%) \\
\hline SCMR at tillering stage & 39.97 & 39.37 & 40.53 & 38.07 & 38.25 & 38.43 & 0.45 & 1.31 \\
\hline SCMR at flowering stage & 43.63 & 42.77 & 45.27 & 41.21 & 42.28 & 43.05 & 0.46 & 1.32 \\
\hline SCMR at maturity stage & 34.67 & 34.43 & 35.00 & 33.83 & 33.22 & 34.27 & 0.39 & 1.13 \\
\hline Photosynthetic rate at tillering stage $\left(\mu \mathrm{mol} \mathrm{CO}_{2} \mathrm{~m}^{-2} \mathrm{~s}^{-1}\right)$ & 20.07 & 19.18 & 20.99 & 19.91 & 20.26 & 19.68 & 0.48 & 1.38 \\
\hline Photosynthetic rate at flowering stage $\left(\mu \mathrm{mol} \mathrm{CO}_{2} \mathrm{~m}^{-2} \mathrm{~s}^{-1}\right)$ & 24.22 & 23.53 & 27.35 & 26.28 & 24.81 & 24.56 & 0.59 & 1.71 \\
\hline Photosynthetic rate at maturity stage $\left(\mu \mathrm{mol} \mathrm{CO}_{2} \mathrm{~m}^{-2} \mathrm{~s}^{-1}\right)$ & 13.20 & 13.50 & 16.59 & 16.01 & 15.41 & 16.13 & 0.51 & 1.46 \\
\hline No. of filled grains hill- ${ }^{-1}$ & 1502.67 & 1352.67 & 1578.67 & 1487.85 & 1454.07 & 1368.53 & 27.08 & 78.21 \\
\hline 1000 grain wt $(\mathrm{g})$ & 22.05 & 16.46 & 19.93 & 18.38 & 15.65 & 15.37 & 0.43 & 1.25 \\
\hline NUE & 44.26 & 42.67 & 46.17 & 42.94 & 43.77 & 42.71 & 0.37 & 1.08 \\
\hline Grain yield $\left(\mathrm{kg} \mathrm{ha}^{-1}\right)$ & 5311.50 & 5120.63 & 5539.80 & 5153.04 & 5252.39 & 5125.73 & 38.83 & 112.14 \\
\hline
\end{tabular}

Recurrent selection, biparental mating and diallel selective mating system may also be profitable to exploit both additive and non-additive components for bringing about improvement in grain yield and its attributes. Such a strategy will help in increasing the frequency of favorable alleles while maintaining the genetic variation in breeding population (Hallauer and Miranda, 1988 and Doerksen et al., 2003) ${ }^{[6,5]}$.

\section{Conclusion}

Improvement of traits with simple selection techniques will not be able to fix superior lines in the early segregating generations. Knowledge about the way genes act and interact will determine the breeding system to optimize gene action more efficiently to elucidate the role of breeding systems in the evolution of crop plants. Cultivars with high uptake efficiency had higher nitrogen contents than cultivars with low uptake efficiency from nitrogen application. This could reduce the losses of $\mathrm{N}$ and facilitates increased $\mathrm{N}$ uptake and result in the development of superior nitrogen use efficient rice cultivars.

\section{References}

1. Ahrens TD, Lobell DB, Ortiz-Monasterio JI, Li Y, Matson PA. Narrowing the agronomic yield gap with 
improved nitrogen use efficiency: a modeling approach. Ecological Applicants 2010;20:91-100.

2. Bahmanyar MA, Ranjbar GA. Response of rice cultivar to rates of nitrogen and potassium application in field and pot conditions. Pakistan Journal of Biological Sciences 2007;10(9):1430-1437.

3. Bharali B, Chandra K. Effect of low light on dry matter production, harvest index and grain yield of rice (Oryza sativa L.) in wet season. Neo-Botanica 1994;2(1):11-14.

4. Cassman KG, Kropff MG, Gaunt J, Peng S. Nitrogen use efficiency of irrigated rice: what are the key constraints? Plant and Soil 1993;1:155-156.

5. Doerksen TK, Kannenberg L, Lee E. Effects of recurrent selection on combining ability in maize breeding population. Crop science 2003;43:1652-1668.

6. Hallauer AR, Miranda JB. Quantitative Genetics in Maize Breeding. The Iowa State University Press, Ames, USA 1988.

7. Hassan MS, Abul Khair, Haque MM, Abdul Hamid. Photosynthetic characters, SPAD value and nitrogen use efficiency of traditional AUS rice (Oryza sativa L.) cultivars. SAARC Journal of Agriculture 2007;5(2):2940.

8. Islam MS, Bhuiya MSU, Rahman S, Hussain MM. Evaluation of SPAD and LCC based nitrogen management in rice (Oryza sativa L.). Bangladesh Journal of Agriculture Research 2009;34(4):661-672.

9. Kang SG, Hassan MS, Sang WG, Min-Kyu Choi, YoungDoo Kim, Hong-Kyu Park et al. Nitrogen use efficiency of high yielding japonica rice (Oryza sativa L.) influenced by variable nitrogen applications. Korean journal of Crop Science 2013;58(3):213-219.

10. Keasrey MJ, Pooni HS. The Genetical Analysis of Quantitative Traits. Chapman and Hall. First Edition. London 1996.

11. Lea PJ, Miflin BJ. Glutamate synthase and the synthesis of glutamate in plants. Plant Physiol. Biochem 2003;41:555-564.

12. Ligeng J, Dong D, Gan X, Wei S. Photosynthetic efficiency and nitrogen distribution under different nitrogen management and relationship with physiological nitrogen use efficiency in three rice genotypes. Plant and Soil 2005;271:321-328.

13. Miah MAM, Ahmed ZU. Comparative efficiency of the chlorophyll meter technique, urea super granule and prilled urea for hybrid rice in Bangladesh. In: "Hybrid Rice in Bangladesh: Progress and Future Strategies". Bangladesh Rice Research Institute 2002;138:43-50.

14. Miah MNH, Yoshida T, Yomamoto Y. Effect of nitrogen application during ripening period on photosynthesis and dry matter production and its impact on yield and yield components of semi dwarf indica rice varieties under water culture conditions. Soil Science and Plant Nutrition 1997;43(1):205-217.

15. Pathak RR, Altaf A, Sunila L, Raghuram N. Molecular physiology of plant nitrogen use efficiency and biotechnological options for its enhancement. Current Science 2008;94(11):1394-1403.

16. Singh B, Singh Y, Ladha JK, Bronson KV, Balasubramanian V, Singh J et al. Chlorophyll Meter and Leaf Color Chart Based Nitrogen Management for Rice and Wheat in Northwestern India. Agronomy Journal 2002;94:821-829.
17. Singh RK, Chaudhary BD. Biometrical Methods in Quantitative Genetic Analysis. Kalyani Publishers New Delhi India 2001,79-101.

18. Swain DK, Jagtap K, Sandip S. Development of spad values of medium-and long duration rice variety fo rsitespecific nitrogen management. Journal of Agronomy 2010;9(2):38-44.

19. Tahir M, Wadan D, Zada A. Genetic Variability of Different Plant Yield Characters in Rice. Sarhad Journal of Agriculture 2002,18(2).

20. Wilson JA, Glover DV, Nyquist WE. Genetic effects of the soft starch (h) and background loci on volume of starch granules in five inbreds of maize. Plant Breeding 2000;119:173-176.

21. Win KT, Mochizuki T. Physiological efficiency under different nitrogen nutrition conditions and relationship with photosynthetic nitrogen use efficiency in Myanmar local rice varieties (Oryza sativa L.). Journal of Faculty Agriculture 2010;55(1):61-66.

22. Zhao L, Wu L, Wu M, Li Y. Nutrient uptake and water use efficiency as affected by modified rice cultivation methods with irrigation. Paddy Water Environment 2011;9:25-32. 